\title{
SALT LAKES, CLIMATE CHANGE, AND HUMAN IMPACT: A MICROBIOLOGIST'S PERSPECTIVE
}

\author{
A. OREN $N^{1}$
}

\begin{abstract}
Salt lakes, climate change, and human impact: a microbiologist's perspective. The world's major salt lakes are rapidly drying out due to water diversion for irrigation, climatic changes and other causes. The accompanying increase in salinity and other changes in the physico-chemical properties have a profound impact on the microbial communities which are the basis of the food web. This paper gives an overview of the changes in the microbial communities and their activities that have occurred in the past decades in Great Salt Lake, the Dead Sea, Lake Urmia and the Aral Sea. In-depth knowledge of the microbial populations and the biogeochemical processes they perform is essential for the proper understanding of current functioning of salt lake ecosystems and for the prediction of the consequences of future changes in these unique environments.
\end{abstract}

Keywords: salt lakes, Great Salt Lake, Dead Sea, Lake Urmia, Aral Sea.

\section{INTRODUCTION}

Many of the world's saline and hypersaline lakes are rapidly shrinking. Global warming and climate change are in part responsible for the drying out of salt lakes, but in most cases diversion of freshwater from the lakes' drainage areas for irrigation and other forms of human use is the major cause of the decline (Wurtsbaugh et al., 2017).

Microorganisms, including microalgae, heterotropic bacteria and archaea, form the basis of salt lake ecosystems. The salinity and the ionic composition determine what kinds of microorganisms can develop and what microbial processes can function in a certain environment. Accordingly, microorganisms are sensitive indicators for the enviromental conditions in salt lakes. Drying out of salt lakes results in qualitative and quantitative changes of the microbial communities. Farreaching changes in the microbiological properties can also be expected to occur following attempts to mitigate the past changes.

This paper presents an overview of the properties of four major salt lakes whose surface area has dramatically decreased in the past decades: Great Salt Lake, the Dead Sea, the Aral Sea and Lake Urmia (Fig. 1), with special emphasis on our understanding of the dynamics of the microbial communities inhabiting these lakes in the past and in the present.

1 Department of Plant and Environmental Sciences, The Institute of Life Sciences, The Hebrew University of Jerusalem, Jerusalem 9190401, Israel, E-mail: aharon.oren@mail.huji.ac.il 


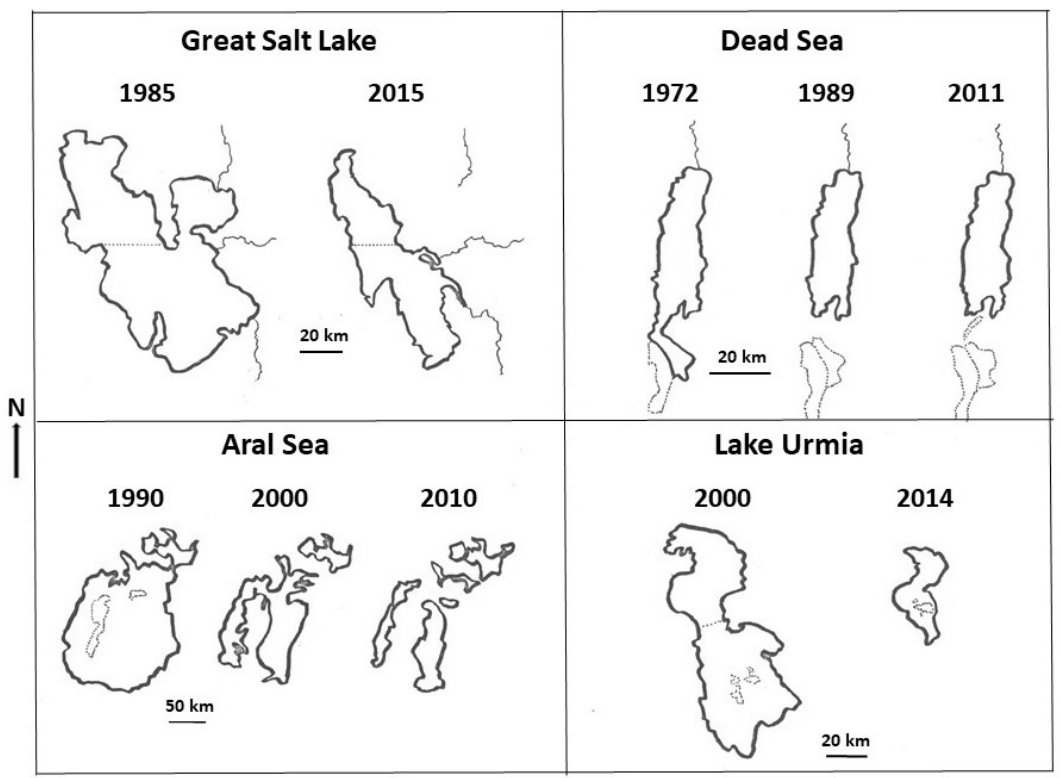

Fig. 1. The decline of Great Salt Lake, the Dead Sea, the Aral Sea, and Lake Urmia, in the past decades. Maps are based on satellite photographs taken between 1972 and 2015.

\section{GREAT SALT LAKE, UTAH}

Great Salt Lake is a remnant of the glacial Lake Bonneville, which covered an area about $52,000 \mathrm{~km}^{2}$. In 1988 the lake covered an area of about $8,500 \mathrm{~km}^{2}$. In 1959 , a rock-filled railway causeway was constructed, separating the lake into a north and south arm. As the south arm receives most of the incoming streamflow, a salinity gradient developed. The north arm is now at, or near, salinity saturation (Gwynn, 2002; White et al., 2015). Today the lake is 3.6 meters below its 1847 level and just half its original volume. The rapid drying-out of the lake was mainly due to consumptive water use (Deroulin, 2017; Wurtsbaugh et al., 2017).

The lake harbors a complex food web, including different types of phytoplankton, bacteria and archaea, brine shrimp (Artemia franciscana), corixids, and eared grebes. The phytoplankton community is limited by nitrogen availability and by brine shrimp grazing (Marcarelli et al., 2006; Belovsky et al., 2014). From 1982 to 1987 unusually heavy rainfall caused a rise in lake elevation accompanied by large decreases in salinity in both parts. As a result, obligate halophilic microalgae such as Dunaliella salina and D. viridis were outcompeted by opportunistic forms such as the cyanobacterium Nodularia spumigena (Stephens, 1990). The drying out of the lake in recent years has reversed the process. Opening of a new breach in the railroad causeway in 2016 will facilitate more efficient bidirectional flow and cause further changes in nutrient pools (Naftz, 2017).

Microbiological studies in the 1970s showed that the brines of the north arm were red due to dense communities of halophilic archaea (Post, 1977). The first 
cultivation-independent studies of the north arm (Baxter et al., 2005) showed similar archaeal communities during 2003 and 2004, but the diversity changed in 2005 and 2006. The Salinibacter group dominated the bacterial populations. About 20-23 phylotypes of archaea were detected; some, such as Haloquadratum, were present year-round (Almeida-Dalmet et al., 2015). Cultivation-independent studies of the archaeal, bacterial, and eukaryal community composition were also performed along the stratified water column in the south arm. The greatest diversity was found at the strong physicochemical gradients of the halocline (Meuser et al., 2013). In a more recent study, the archaeal and bacterial communities at the north and south arms were surveyed. Here 58 archaeal and 42 bacterial 16S rRNA-based operational taxonomic units were identified, most of which representing novel phylotypes (Tazi et al., 2014).

\section{THE DEAD SEA}

In the past decades the water level of the Dead Sea (maximum depth $\sim 300$ $\mathrm{m})$ has decreased by more than a meter annually. Presently (2018) the level is about 431 meters below mean sea level. This negative water balance is mainly due to the diversion of water from the catchment area of the lake by Israel, Jordan and Syria and by pumping water from the lake into the evaporation ponds for extracting potash and other salts by the Dead Sea Works (Israel) and the Arab Potash Company (Jordan). Today, Dead Sea water contains $\sim 340 \mathrm{~g} / 1$ salts and has a density of $\sim 1.24 \mathrm{~g} / \mathrm{ml}$. Magnesium rather than sodium is the main cation in this 'athalassohaline' brine. Large amounts of $\mathrm{NaCl}$ have precipitated to the bottom in the past thirty years, leading to an ever increasing ratio of $\mathrm{Mg}^{2+}$ and $\mathrm{Ca}^{2+}$ relative to $\mathrm{Na}^{+}$. Thus, $\mathrm{Na}^{+}$decreased from $1.73 \mathrm{M}$ in 1977 to $1.25 \mathrm{M}$ in 2007 , while $\mathrm{Mg}^{2+}$ increased from 1.81 M to 2.09 M. As a result the Dead Sea has become an ever more extreme environment even for the best salt-adapted microorganisms (Oren, 2000).

Until 1979 the Dead Sea was meromictic. Following the lowering of the water level, complete mixing occurred in 1979. Since then the lake is monomictic, with the exception of two short meromictic episodes (1980-1982 and 1992-1995) when large rain floods caused a new stratification (Gavrieli and Oren, 2004).

Several species of halophilic archaea have been isolated from the Dead Sea, including Haloferax volcanii, Haloarcula marismortui, Halorubrum sodomense, and Halobaculum gomorrense. The lake has also yielded isolates of halophilic bacteria and fungi. The first quantitative survey of its microbiota was made in 1963-1964 (Kaplan and Friedmann, 1970). Dense blooms of the alga Dunaliella and of halophilic archaea developed in 1980 and in 1992, following dilution of the upper meters of the water column by rain floods. These blooms imparted a red color to the brine (Oren, 1985, 2000; Oren and Gurevich, 1995; Oren and Shilo, 1982; Oren et al., 1995). Dunaliella blooms only develop in the Dead Sea when two conditions are fulfilled: the salinity of the upper water layers must become sufficiently low, and phosphate must be available (Oren and Shilo, 1985; Oren et al., 2004). Cultivation-independent studies showed a low diversity of 
halophilic archaea in the 1992 bloom and a small but diverse community in 2007 (Bodaker et al., 2010). Recent high-throughput amplicon sequencing of rRNA gene sequences also showed significant presence of bacteria (Jacob et al., 2017). Abundant and diverse microbial life was found in biofilms covering rocks and sediments around underwater freshwater springs and seeps (Ionescu et al., 2012).

During the 2002 World Summit on Sustainable Development, Israel and Jordan jointly announced their interest in saving the Dead Sea by constructing a pipeline (the "Peace Conduit") between the Red Sea and the Dead Sea to refill the shrinking Dead Sea and to desalinate seawater. Extensive studies have been performed since to evaluate the environmental impact of such a project (Gavrieli and Oren, 2004; Gavrieli et al., 2005; Coyne et Bellier, 2012).

\section{LAKE URMIA}

Lake Urmia is located in Iran's northwestern corner at an elevation of 1,275 $\mathrm{m}$ above sea level, Until 2-3 decades ago it covered $\sim 6,000 \mathrm{~km}^{2}$, being even larger than Great Salt Lake. It had a rich ecosystem that included the endemic Artemia urmiana, used as feed by flamingos and other waterfowl. After the rivers that supplied most of the water to the lake had been dammed for irrigation and hydropower, less than $10 \%$ of the original lake surface is left, exposing a salt desert, and the beautiful ecosystem was destroyed. More than 20 years ago a 15-kilometerlong causeway was built in the middle of the lake, and that causeway now separates mostly dry lakebed to the south from a relict lake, saturated with salt. Attempts are underway to restore the brine shrimp populations and the accompanying wildlife in small embayments (Stone, 2015). It was estimated that annually $3.7 \cdot 10^{9} \mathrm{~m}^{3}$ water is needed to preserve Lake Urmia. With the current climate change even reduction of water diversion and irrigation will not stabilize the ecosystem (Shadkam et al., 2016).

As in most hypersaline lakes, the unicellular green alga Dunaliella is the main primary producer. To estimate the current biodiversity of Dunaliella strains in the lake, a survey was made based on $18 \mathrm{~S}$ rRNA gene comparisons and intron-sizing. Different parts of the lake harbored different genetic populations. This biodiversity is now threatened because of the drying-out of the lake (Hejiazi et al., 2016). The first microbiologial suvey of Lake Urmia was published only in 2011. Using a cultivation-dependent approach, 37 halophilic or halotolerant bacteria were isolated, most of which belonged to the Gammaproteobacteria (Salicola, Pseudomonas, Marinobacter, Idiomarina, Halomonas) and the Firmicutes (Bacillus, Halobacillus). Some of these may represent novel species (Vahed et al., 2011). Following the increase in salinity, extremely halophilic archaea became a more important part of the community, but quantitative data are lacking. Two novel species of haloarchaea (class Halobacteria) were recently documented from the lake, both representing novel genera: the orange-pigmented pleomorphic Halosiccatus urmianus (family Haloarculaceae) and Halovarius luteus (family Natrialbaceae) (Mehrshad et al., 2015, 2016). 


\section{THE ARAL SEA}

In 1960, the Aral Sea, located between Kazakhstan and Uzbekistan, was the fourth largest lake in the world by water surface area with a total area of $68,500 \mathrm{~km}^{2}$ and a volume of $1,089 \mathrm{~km}^{3}$. The maximum depth was $69 \mathrm{~m}$. The lake was only slightly saline (average salinity $\sim 10 \mathrm{~g} / 1$ ). The lake was inhabited by 12 species of fish and $\sim 160$ species of free-living invertebrates, not including protozoa and small-size metazoa. By 2007 the Aral covered $\sim 13,958 \mathrm{~km}^{2}$ (21\% of 1960) with a volume of $102 \mathrm{~km}^{3}$ (9\% of 1960). The Large Aral (the southern part) was $10,700 \mathrm{~km}^{2}(17 \%$ of $1960)$ and had a volume of $75 \mathrm{~km}^{3}$ (8\% of 1960), salinity being $>100 \mathrm{~g} / \mathrm{l}$. The respective values for the Small Aral were $3,258 \mathrm{~km}^{2}$ (53\% of 1960) and $27 \mathrm{~km}^{3}(33 \%$ of 1960), with an average salinity of about $10 \mathrm{~g} / \mathrm{l}$. The lake has split into six separate water bodies (Aladin et al., 1995; Micklin, 2007; Micklin and Aladin, 2008).

The ecological and economic disaster of the drying-out of the Aral Sea is excellently summarized in the 2009 "St. Petersburg Statement on the Aral Sea", issued at the end of an international conference dealing with all aspects of the lake $(* * *, 2009)$. The (abridged and edited) highlights of that statement are given here:

1. The Aral Sea has undergone unprecedented shrinking and salinization since the 1960s. These processes have had serious negative ecologic impacts on the lake and deltas of its two influent rivers (the Syr Darya and the Amu Darya).

2. To place the post-1960 recession in context, it is essential to understand that the lake has experienced repeated recessions and transgressions since it most recent geological incarnation some 10,000 years ago. These have resulted from natural climate change, development of irrigation in the lake's basin, and repeated shifts of the beds of the two influent rivers from the Aral westward to the Caspian Sea or into the desert.

3. The chief factor leading to the recent drying-out of the Aral Sea was the expansion of irrigation in the sea's drainage basin from the mid-1950s to the mid1980s. Global warming also started to influence the lake's water balance.

4. Redirection of Siberian rivers southward to the Aral Sea Basin or pumping of water from the Caspian Sea to the Aral are not realistic options for solving the water problems in Central Asia.

5. Water inflow through the Amu Darya and the Syr Darya is the key factor determining both the lake's size and ecological quality. Lobbying for agricultural reform and rational water use is necessary at all levels of government and society.

6. Reports of the Aral Sea's death are premature. Although the Aral Sea of the 1960s is gone for the foreseeable future, sizable parts of the lake remain. The Small Aral Sea has been partially, and so far very successfully restored (following the creation of a dike at Berg's Strain in 1992 and an improved version in 2005), so that it again has significant ecological and economic value. The Western Basin could be partially preserved and restored.

Except for limited phytoplankton data (Izhitskiy et al., 2016) no studies have been published on the changes in the microbiology of the Aral Sea as a function of 
salinity changes since 1960. A first evaluation of the microbial communities present in the different parts of the lake and their activities is long overdue.

\section{FINAL COMMENTS}

Salt lakes are fascinating environments for microbiological exploration, as the diversity of the microbial communities and their activities are excellent indicators of the state of the lakes with respect to salinity, nutrients, and other environmentally important parameters. Although the four large lakes discussed above differ in many properties, they also resemble each other in many aspects, including the rapid drying out and increasing salinities due to a combination of human interference (first and foremost) and climate change. A comparison of the past, present, and (planned) future properties of the Aral Sea and the Dead Sea showed many striking similarities (Oren et al., 2010). And as the case of the Dead Sea shows, understanding of the microbial processes is essential for the prediction of environmental changes that may take place when large-scale projects will be implemented to mitigate the drying out of the world's large hypersaline lakes. For Great Salt Lake and the Dead Sea we have a relatively good understanding of the microbial communities and the processes they perform, but much remains to be learned about the microbes inhabiting these lakes and the impact of possible future changes, climatic as well as man-made, in the physical and chemical properties of their waters. Other major salt lakes such as Lake Urmia and the Aral Sea remain virtually unexplored as far as the microbial communities are concerned.

Recently, Paul and Mormile (2017) issued a call for the protection of saline and hypersaline environments from a microbiological perspective. Saline lakes worldwide are threatened by increased salinization due to water diversions, global climate change, industrial processes, pollution, and other factors. An in-depth knowledge of the microbial populations and the biogeochemical processes they perform is essential for the proper understanding of the current functioning of salt lake ecosystems and for the prediction of the consequences of future changes in these unique environments.

\section{REFERENCES}

1. Aladin N.V., Plotnikov, I.S., and Potts, W.T.W. (1995), The Aral Sea desiccation and possible ways of rehabilitating and conserving its northern part. Int. J. Environmetr. 6, 17-29.

2. Almeida-Dalmet, S., Sikaroodi, M., Gillevet, P.M., Litchfield, C.D., and Baxter, B.K. (2015), Temporal study of the microbial diversity of the north arm of Great Salt Lake, Utah, U.S. Microorganisms 3, 310-326.

3. Baxter, B.K., Litchfield, C.D., Sowers, K., Griffith, J.D., Arora DasSarma, P., et al. (2005), Microbial diversity of Great Salt Lake. In: Gunde-Cimerman, N., Oren, A., and Plemenitaš, A. (eds.), Adaptation to Life at High Salt Concentrations in Archaea, Bacteria, and Eukarya. Springer, Dordrecht, pp. 9-25.

4. Belovsky, G.E., Stephens, D., Perschon, C., Birdsey, P., Paul, D., et al. (2014), The Great Salt Lake Ecosystem (Utah, USA): long term data and a structural equation approach. Ecosphere 2, 33. 
5. Bodaker, I., Sharon, I., Suzuki, M.T., Reingersch, R., Shmoish, M., et al. (2010), Comparative community genomics in the Dead Sea: an increasingly extreme environment. ISME J 4, 399-407.

6. Coyne et Bellier, Tractebel Engineering, and Kema (2012), Red Sea-Dead Sea Water Conveyance Study Program: Draft Feasibility Study Report. Report No. 12147 RP 04. July 2012.

7. Deroulin, S. (2017), Utah's Great Salt Lake has lost half its water, thanks to thirstry humans. Science ... doi:10.1126/science.aar3941.

8. Gavrieli, I., and Oren, A. (2004), The Dead Sea as a dying lake. In: Nihoul, J.C.J., Zavialov, P.O., and Micklin, P.P. (eds.), Dying and Dead Seas. Climatic versus Anthropic Causes. Kluwer Academic Publishers, Dordrecht, pp. 287-305.

9. Gavrieli, I., Bein, A., and Oren, A. (2005), The expected impact of the "Peace Conduit" project (the Red Sea - Dead Sea pipeline) on the Dead Sea. Mitigation and Adaptation Strategies for Global Change 10, 3-22. Erratum: p. 739 and pp. 759-777.

10. Gwynn, J.W. (ed.) (2002), Great Salt Lake, An Overview of Change. Special Publication of the Utah Department of Natural Resources, Salt Lake City, Utah.

11. Hejiazi, M.A., Khoshrouy, R., Hosseinzadeh Gharajeh, N., Etemadi, M.R., Madayen, L., et al. (2016), Conservation and biodiversity analysis of the microalga Dunaliella in shrinking highly saline Urmia Lake based on intron-sizing method. J. Agr. Sci. Tech. 18, 1693-1703.

12. Ionescu, D., Siebert, C., Polerecky, L., Munwes, Y.Y., Lott, C., et al. (2012), Microbial and chemical characterization of underwater fresh water springs in the Dead Sea. PLoS One 7, e38319.

13. Izhitskiy, A.S., Zavialov, P.O., Sapozhnikov, P.V., Kirillin, G.B.., Grossart, H.P., et al. (2016), Present state of the Aral Sea: diverging physical and biological characteristics of the residual basins. Sci. Rep. 6, 23906.

14. Jacob, J.H., Hussein, E.I., Shakhatreh, M.A.K, and Cornelison, C.T. (2017), Microbial community analysis of the hypersaline water of the Dead Sea using highthroughput amplicon sequencing. MicrobiologyOpen 6, e500.

15. Kaplan, I.R., and Friedmann, A. (1970), Biological productivity in the Dead Sea. Part 1. Microorganisms in the water column. Israel J. Chem. 8, 513-528.

16. Marcarelli, A.M., Wursbaugh, W.A., and Griset, O. (2006), Salinity controls phytoplankton response to nutrient enrichment in the Great Salt Lake, Utah, USA. Can. J. Fish Aquat. Sci. 63, 2236-2248.

17. Mehrshad, M., Amoozegar, M.A., Makhdoumi, A., Rasooli, M., Asadi, B., et al. (2015). Halovarius luteus gen. nov., sp. nov., an extremely halophilic archaeon from a salt lake. Int. J. Syst. Evol. Microbiol. 65, 2420-2425.

18. Mehrshad, M., Amoozegar, M.A., Makhdoumi, A., Fazeli S.A.S., Farahani, H., et al. (2016), Halosiccatus urmianus gen. nov, sp. nov., a haloarchaeon from a salt lake. Int. J. Syst. Evol. Microbiol. 66, 725-730.

19. Meuser, J.E., Baxter, B.K., Spear, J.R., Peters, J.W., Posewitz M.C. et al. (2013), Contrasting patterns of community assembly in the stratified water column of Great Salt Lake, Utah. Microb. Ecol. 66, 268-280.

20. Micklin, P. (2007), The Aral Sea disaster. Ann. Rev. Earth Planet. Sci. 35, 47-72.

21. Micklin, P., and Aladin, N.V. (2008), Reclaiming the Aral Sea. Sci. Am. April 2008, 44-51.

22. Naftz, D. (2017), Inputs and internal cycling of nitrogen to a causeway influenced, hypersaline lake, Great Salt Lake, Utah. Aquat. Geochem. 23, 199-216. 
23. Oren, A. (1985), The rise and decline of a bloom of halobacteria in the Dead Sea. Limnol. Oceanogr. 30, 911-915.

24. Oren, A. (2000), Biological processes in the Dead Sea as influenced by short-term and long-term salinity changes. Arch. Hydrobiol. Spec. Issues Advanc. Limnol. 55, 531-542.

25. Oren, A., and Gurevich, P. (1995), Dynamics of a bloom of halophilic archaea in the Dead Sea. Hydrobiologia 315, 149-158.

26. Oren, A., and Shilo, M. (1982), Population dynamics of Dunaliella parva in the Dead Sea. Limnol. Oceanogr. 27, 201-211.

27. Oren, A., and Shilo, M. (1985), Factors determining the development of algal and bacterial blooms in the Dead Sea: a study of simulation experiments in outdoor ponds. FEMS Microbiol. Ecol. 31, 229-237.

28. Oren, A., Gurevich, P., Anati, D.A., Barkan, E., and Luz, B. (1995), A bloom of Dunaliella parva in the Dead Sea in 1992: biological and biogeochemical aspects. Hydrobiologia 297, 173-185.

29. Oren, A., Gavrieli, I., Gavrieli, J., Lati, J., Kohen, M., et al. (2004), Biological effects of dilution of Dead Sea water with seawater: implications for the planning of the Red Sea-Dead Sea "Peace Conduit". J. Mar. Syst. 46, 121-131.

30. Oren, A. Sokolov, S., Plotnikov, I.S., and Aladin, N.V. (2010), The Aral Sea and the Dead Sea: disparate lakes with a similar history. Lakes \& Reservoirs Res. Manag. 15, 223-236.

31. Paul, V.G., and Mormile, M.R. (2017), A case for the protection of saline and hypersaline environments: a microbiological perspective. FEMS Microbiol. Ecol. 93, fix091.

32. Post, F.J. (1977), The microbial ecology of the Great Salt Lake. Microb. Ecol. 3, 143-165.

33. Shadkam, S., Ludwig, F., van Vliet, M.T.H., Pastor, A., and Kabat, P. (2016), Preserving the world second largest hypersaline lake under future irrigation and climate change. Sci. Total Environ. 559, 317-325.

34. Stephens, D.W. (1990), Changes in lake levels, salinity and the biological community of Great Salt Lake (Utah, USA), 1847-1987. Hydrobiologia 197, 139146.

35. Stone, R. (2015), Saving Iran's Great Salt Lake. Science 349, 1044-1045, 1047.

36. Tazi, L., Breakwell, D.P., Harker, A.R., and Crandall, K.A. (2014), Life in extreme environments: microbial diversity in Great Salt Lake, Utah. Extremophiles 18, 525-545.

37. Vahed, S.Z., Forouhandeh, H., Hassanzadeh, S., Klenk, H.-P., Hejazi, M.A., et al. (2011), Isolation and characterization of halophilic bacteria from Urmia Lake in Iran. Microbiology 80, 834-841.

38. White, J.S., Null, S.E., and Tarboton, D.G. (2015), How do changes to the railroad causeway in Utah's Great Salt Lake affect water and salt flow? PLoS One 10, e0144111.

39. Wurtsbaugh, W.A., Miller, C., Null, S.E., DeRose R.J., Wilcock, P., et al. (2017), Decline of the world's saline lakes. Nat. Geosci. 10, published online 23 Oct. 2017; doi: 10.1038/NGEO03052.

40. *** (2009)., St. Petersburg Statement on the Aral Sea .... http://sic.icwcaral.uz/releases/eng/169.htm, accessed on January, 28, 2018. 